\title{
TINJAUAN SYARI'AH TERHADAP HUKUM PIDANA MATI
}

\author{
Sahid HM \\ Fakultas Syariah IAIN Sunan Ampel Surabaya, Jl. A. Yani I I 7 Surabaya | \\ sahidhm@.yahoo.co.id
}

\begin{abstract}
Abstrak: Hukum pidana mati secara konsepsional dan operasional masih terjadi polemik dan selalu menjadi perbincangan di tengahtengah masyarakat. Kalangan yang kontra menganggap, hukuman mati tidak manusiawi dan bukan merupakan hukuman yang akan memperbaiki tingkah laku seseorang. Bagi kalangan yang pro, alasanalasan itu tidak diterima. Menurut mereka, ketidakmanusiawian itu tidak dapat dilihat dari sudut kepentingan seseorang yang terkena hukuman. Kepentingan si korban, para anggota keluarga, dan masyarakat dapat dijadikan acuan dan pegangan sebagai pertimbangan. Kajian ini membahas tentang tinjauan syari'ah terhadap hukum pidana mati dalam perspektif keadilan dan kemanusian. Menurut syari'ah, hukum pidana Islam adalah hukum yang setimpal; orang yang membunuh, dia harus dibunuh kecuali jika pihak keluarga terbunuh memberikan pengampunan atau meminta ganti rugi. Selain itu, hukuman itu dapat dilihat dari segi kemaslahatan secara totalitas, bukan kemaslahatan secara parsial. Oleh karena itu, hukum pidana mati pada hakikatnya untuk menjaga hak hidup orang lain demi keadilan dan melesatrikan nilai-nilai kemanusiaan. Dalam pemeriksaan dan pemutusan perkara, hukum pidana mati diterapkan secara fleksibel, transparan, dan manusiawi. Dalam hal ini, hakim melibatkan pihak keluarga korban dengan menanyakan pada pihak keluarga korban tentang kerelaannya untuk memberikan maaf kepada terdakwa.

Kata Kunci: Syari'ah, Hukum Pidana Mati, Keadilan, dan Kemanusiaan.
\end{abstract}

\section{Pendahuluan}

Di kalangan pakar hukum, hukum pidana mati masih menjadi polemik. Munculnya polemik itu terkait dengan hak hidup seseorang dan nilai kemanusiaan. Pro-kontra di antara mereka sulit dicarikan titik temu dan saling tarik-menarik dalam 
memberlakukan hukum pidana mati. Kesulitan menemukan solusi semakin tampak jika hukum pidana mati dihubungkan pada keadilan dan kemanusiaan yang secara konseptual tidak sama dalam memberikan penilaian.

Fenomena keadilan dan kemanusiaan dalam hukum Islam juga merupakan pokok pembahasan yang selalu menjadi kontroversial. Keadilan dan kemanusiaan adalah nilai universal yang multi dimensi dalam penafsiran. Untuk itu, satu negara dengan negara lain berbeda dalam memberikan kerangka kemanusiaan dan keadilan dalam penerapan. Perbedaan itu terkadang meruncing dan menjadi klaim terhadap pandangan yang tidak satu visi. Anggapan keluar dari syari’ah dari satu pihak menjadi realitas di tengah-tengah masyarakat.

Di sisi lain, hukum Islam tampak vakum dan stagnasi. Dalam kondisi demikian, jurisprudensi dan legislasi Islam sangat membutuhkan basis teoritis yang lebih tegar dan konsisten. ${ }^{1}$ Artinya, hukum Islam dapat diberlakukan secara komprehensip dan berkembang secara konsisten, terutama tentang pemberlakuan hukum pidana mati.

Memperhatikan dinamika di atas, paradigma hukum pidana mati sangat urgen ditelaah yang pada saat sekarang masih menjadi perbincangan aktual bagi para pakar hukum, yang satu menganggap masih relevan sedang yang lain menilai tidak relevan. Fenomena kontekstualisasi kontemporer terhadap hukum pidana mati menurut syari'ah dalam perspektif keadilan dan kemanusiaan menjadi kajian dalam tulisan ini. Untuk itu, pemikiran hukum pidana Islam dalam realitas kontemporer, terutama dalam konteks Indonesia merupakan fenomena menarik untuk dicarikan solusi.

' Joseph Schacht, "Problem of Modern Islamic Legislation," dalam Studia Islamica, vol. 12 (t.t.p.: t.p., 1960), 99. 


\section{Konsepsi Syari’ah dalam Perspektif Hukum}

Hukum Islam adalah kolektivitas aturan religius yang mengatur perilaku kehidupan umat Islam dalam semua aspek, baik secara individual ataupun secara kolektif. Karena karakteristik yang multi dimensi, hukum Islam menempati posisi penting dalam pandangan umat Islam. Sejak semula hukum Islam sudah dianggap sebagai pengetahuan par exellence, yaitu suatu posisi yang belum pernah dicapai oleh teolog. Oleh karena itu, para pengamat Barat menganggap mustahil mengerti Islam tanpa memahami hukum Islam. ${ }^{2}$

Hukum Islam seringkali diidentikkan dengan syari'ah. Kata syari'ah secara etimologis berasal dari kata syara'a yang secara harfiah mempunyai dua arti. Pertama, jalan yang lurus. Kedua, jalan air yang dituju untuk minum. ${ }^{3}$ Di kalangan fuqaha' ungkapan syari'ah kemudian diletakkan secara umum untuk hukum-hukum yang ditetapkan Allah kepada hamba-hamba-Nya ${ }^{4}$ agar mereka bahagia di dunia dan akhirat. Oleh karena itu, sistem hukum yang didasarkan pada wahyu disebut syara' atau syir'ah ${ }^{5}$ yang berarti qanun, misaq, i'lan (peraturan, undang-undang, deklarasi). ${ }^{6}$ Dengan demikian, secara terminologis-menurut teori klasik-syari'ah adalah perintah atau hukum Tuhan yang diwahyukan kepada Muhammad $^{7}$ untuk hamba-hamba-Nya, baik secara konkret maupun tidak. Dalam pemaknaan hukum, syari'ah adalah

2 Joseph Schacht, An Introduction to Islamic Law (London: Oxford at the Clrarendon Press, 197I), I.

${ }^{3}$ Lihat Kamil Musa, al-Madkhal ila al-Tasyri' al-Islami(Beirut: Mu'assasat al-Risalah, t.t.), I7. Syari'ah bukan hanya jalan menuju rid\}a Allah tetapi juga jalan yang dimani oleh seluruh umat Islam, yakni jalan yang dibentangkan oleh Allah melalui Muhammad. Dalam Islam hanya Allah yang berhak menetapkan jalan sebagai petunjuk hidup bagi manusia. Sayyid Qut\}b, Hazla al-Din (The Religion of Islam), (USA: IIFSO Publication Undated, t.t.), 19.

${ }^{4}$ lbid.

${ }^{5}$ Cyril Glasse, Ensiklopedi Islam, ter. Ghufron A. Mas'adi (Jakarta: PT Raja Grafindo Persada, 1996), 379

${ }^{6}$ Atabik Ali dan Ahmad Zuhdi Muhdlor, Kamus Kontemporer Arab-Indonesia (Yogyakarta: Yayasan Ali Maksum Pondok Pesantren Krapyak Yogyakarta, 1997), I 128.

${ }^{7}$ Muhammad Muslehuddin, Filsafat Hukum Islam dan Pemikiran Orientalis: Studi Perbandingan Sistem Hukum Islam, ter. Yudian Wahyudi Asmin (Yogyakarta: Penerbit PT Tiara Wacana Yogya, |991), 45. 
ketentuan atau aturan yang ditekankan pada hukum Islam, bukan pada akidah dan akhlak.

Proses turun wahyu tentang berbagai ayat hukum dalam alQur'an menunjukkan bahwa wahyu itu diturunkan pada saat timbul masalah kemasyarakatan, moral, atau keagamaan yang memerlukan pemecahan. ${ }^{8}$ Dalam hal ini para sahabat bertanya kepada Rasulullah tentang berbagai masalah yang dihadapi mereka untuk mendapatkan jawaban. Secara otomatis, jawaban Rasulullah itu sesuai dengan situasi dan kondisi masyarakat yang mempunyai corak dan ragam yang sangat mungkin berbeda dengan corak dan ragam pada saat ini.

Dalam dinamika sosio-kulturual, realitas kehidupan masyarakat selalu ditandai dengan gerak dan dinamika yang mengantarkan pada perubahan dan perkembangan. Hal ini menandai adanya variasi dan corak hidup yang seringkali berbeda antara yang satu dengan yang lain karena terliput oleh ruang dan waktu secara kontinu. Dinamika masyarakat ini erat kaitannya dengan syari'ah sebagai landasan hidup umat Islam. Di dalam syari'ah juga terdapat gerak dan dinamika yang membimbing dan mengarahkan manusia dalam kehidupan yang selalu berubah dan berkembang sepanjang masa, namun tidak semuanya syari'ah harus berubah. Adanya perubahan dalam syari'ah sebagai sinyalemen elastisitas hukum Islam. Elastisitas hukum Islam itu dapat dilihat antara lain dari sedikitnya jumlah ayat hukum (ayat al-ahkam) dalam al-Qur'an dan hadis. ${ }^{9}$ Meskipun demikian, pada umumnya ayat-ayat hukum itu memuat norma-norma dasar yang bersifat umum.

Dalam realitasnya hukum pidana Islam diasumsikan sebagai hukuman kejam, sadis, dan tidak manusiawi. Setiap mendengar hukum pidana Islam, yang tersirat dalam benak orang yang tidak

8'Abbdur Rah\}man I. Doi, Shariah: The Islamic Law (Malaysia: A.S. Noorden Kuala Lumpur, 1996), 7.

${ }^{9}$ Amir Mu'allim dan Yusdani, ljtihad: Suatu Kontroversi antara Teori dan Fungsi (Yogyakarta: Penerbit Titian llahi Press, 1997), 44. 
setuju tidak lebih dari sekadar hukum potong tangan, hukum rajam, dan qisas yang dikategorikan sebagai vonis. ${ }^{10}$ Asumsiasumsi yang diungkapkan itu lebih sering berlatar belakang politis, bukan metodologis-juridis. Untuk itu, hukum pidana Islam perlu dipandang dalam kajian yang objektif dan bermuara pada pendekatan hukum.

Di Indonesia, hukum pidana mati adalah salah satu hukuman pokok yang tercantum dalam pasal $10 \mathrm{KUHP}$ dan tercantum pada pasal 43 dari Rancangan KUHP Nasional. Dalam pasal tersebut, hukuman mati ditetapkan dalam satu urutan pertama dalam jajaran hukuman pokok. Penetapan hukuman sebagai hukuman pokok dalam pasal 43 Rancangan KUHP Nasional tersebut membari kesan bahwa para pemikir yang tergabung dalam BPHN tetap berpandangan bahwa hukum pidana mati masih dinilai urgen. Dalam RUU KUHP yang sekarang, hukum pidana mati juga dimasukkan dan menjadi kontroversi.

Jenis hukuman yang telah ditentukan oleh KUHP merupakan ketentuan umum yang berlaku bagi setiap peraturan pidana di luar KUHP. Dengan demikian, peraturan di luar KUHP menentukan jenis hukuman tersendiri. Peraturan perundangundangan di luar KUHP yang memuat ancaman hukum pidana mati antara lain Undang-Undang Cek Kosong (UU Nomor 17 Tahun 1964) yang kemudian disebut dengan UU Nomor 12 Tahun 1971 pasal 1. Dalam jurisprudensi di Indonesia, hukum pidana mati pernah dijatuhkan terhadap perkara tindak pidana politik dan tindak pidana kriminal.

Selain di Indonesia, negara lain seperti Malaysia, Singapore, dan Arab Saudi juga memberlakukan hukum pidana mati. Hanya saja mekanisme hukuman yang diberikan kepada pelaku tindak pidana berbeda. Di Malaysia, hukum pidana mati dengan digantung lehernya. Tingkat pelanggaran yang diberikan kepada pelaku tindak pidana juga berbeda. Realitas ini membuktikan

\footnotetext{
${ }^{10}$ Daud Rasyid, Islam dalam Berbagai Dimensinya (Jakarta: Gema Insani Press, 1998), 175.
} 
bahwa sebagian negara menganggap urgen terhadap hukum pidana mati.

Hukum Pidana Mati dalam Konteks Keadilan dan Kemanusiaan

Di negara-negara modern, hukum pidana Islam selalu menjadi perbincangan yang sangat aktual dan kontroversial. Munculnya polemik ini erat kaitannya dengan persoalan hidup dan mati seseorang. Debat pro dan kontra sulit terselesaikan karena menyangkut hak hidup dan nilai-nilai kemanusiaan.

Kalangan yang kontra menganggap, hukuman mati tidak manusiawi dan bukan merupakan hukuman yang akan memperbaiki tingkah laku seseorang. Bagi kalangan yang pro, alasan-alasan itu tidak diterima. Mereka berpendapat, anggapan tidak manusiawi itu tidak hanya dapat dilihat dari sudut kepentingan seseorang yang harus dihukum, tetapi harus dilihat dari sudut kepentingan si korban dan para anggota keluarganya, bahkan kepentingan masyarakat secara luas. ${ }^{11}$

Kontroversi-kontroversi yang muncul itu mengarah pada tuntutan keadilan yang seimbang antara orang yang melanggar dan ketentuan hukum yang diberikan kepadanya. Pemberlakuan hukum Islam yang ditetapkan selalu mengacu kepada materi yang terdapat dalam al-Qur'an dan al-Sunnah yang diberlakukan secara totalitas, meskipun suatu negara dengan negara yang lain sangat berbeda. Ketentuan ini membawa dampak pada tuntutan reaktualisasi dan rekonstruksi hukum pidana Islam dengan tidak memberlakukan secara paksa, tetapi melihat kondisi aktual masyarakat dan budaya mereka. Konsepsi ini mengacu pada nilai keadilan secara universal. Meskipun demikian, di antara fuqaha' ada yang memandang bahwa hukum yang ditentukan Tuhan sudah mengandung keadilan. Dua konsepsi itu sama-sama menekankan pada aspek keadilan. Oleh karenanya, dalam

\footnotetext{
"Hartono Mardjono, Menagakkan Syariat Islam dalam Konteks Keindonesiaan: Proses Penerapan Nilai-nilai Islam dalam Aspek Hukum, Politik, dan Lembaga Negara (Bandung: Penerbit Mizan, 1997), 112.
}

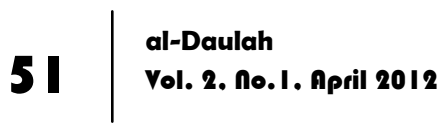


berbagai diskursus hukum, adil selalu menjadi penekanan yang paling utama.

Konsep keadilan yang menyeluruh dalam syari'ah didasarkan pada saling menghormati antara yang satu dengan yang lain. Masyarakat yang adil dalam Islam, berarti masyarakat yang menjamin hak, harkat, dan martabat setiap orang dalam berbagai aturan masyarakat sesuai dengan kepentingan semua anggota. ${ }^{12}$ Semua anggota masyarakat memiliki hak yang sama dalam berbagai aturan, tidak ada diskriminasi. Mereka sama-sama mempunyai hak dan kewajiban.

Adil adalah term yang komprehensip dan meliputi semua norma tingkah laku yang baik. Namun agama Islam menuntut hal yang lebih mendalam dan manusia, yaitu agar mengerjakan berbagai kebaikan sekalipun semuanya itu mungkin tidak dituntut oleh rasa keadilan itu sendiri seperti membalas kebaikan atas kejahatan. ${ }^{13}$ Untuk itu, rasa keadilan diupayakan seoptimal mungkin dalam realisasinya agar pihak-pihak yang terkena sanksi hukum dan orang yang terlibat di dalamnya merasa puas dengan ketetapan syari'ah yang telah diberikan.

Di dalam al-Qur'an term keadilan sering dilangsir. Allah memberi perintah kepada siapapun agar berbuat adil. Keadilan harus ditegakkan oleh semua orang sekalipun bertentangan dengan kepentingan diri sendiri, orang tua, atau keluarga. Tidak ada perbedaan antara si kaya dan si miskin, semua adalah hamba Allah. ${ }^{14}$ Berpijak pada keadilan ini, pemahaman syari'ah diinterpretasikan dan dijabarkan dengan diskursus yang objektif, baik secara deduksi maupun induksi sesuai dengan tatanan masyarakat yang berlaku berdasarkan prinsip keadilan.

Bertitik tolak dari prinsip bahwa hak menetapkan legislasi adalah hak Tuhan, maka fungsi manusia sesungguhnya adalah pelaksana hukum yang telah ditetapkan oleh Tuhan. Manusia

\footnotetext{
${ }^{12}$ Doi, Shariah, 8.

${ }^{13}$ bid., 3.

${ }^{14}$ al-Qur'an, 16:90; 4:135.
} 
tidak berrhak merekayasa sendiri hukum untuk diterapkan dalam kehidupan mereka kecuali dalam batas-batas yang diperbolehkan. ${ }^{15}$ Untuk itu, pelaksanaan berdasarkan rekayasa sendiri adalah pelanggaran terhadap hak otoritas Tuhan sebagai legislator dan pengatur alam semesta.

Secara filosofis hukum pidana Islam adalah setimpal dengan kejahatan yang dilakukan. Orang yang membunuh harus dibunuh. Jika pembunuh tidak divonis dengan hukuman yang setimpal, hal ini berdampak kepada ketidakpuasan pihak keluarga terbunuh. Kondisi ini sangat mungkin bagi pihak keluarga melampiaskan ketidakpuasannya kepada pembunuh atau kepada keluarga terbunuh. Dengan demikian, efek negatif tentu lebih besar daripada positifnya.

Dalam tataran semacam itu, stressing inti dalam al-maqasid alsyar'iyah (tujuan syara') tentang hukuman dalam Islam adalah untuk kemaslahatan umat secara totalitas, bukan kemaslahatan yang bersifat parsial. Syari'ah memperkenalkan tiga kemaslahatan, yaitu maslahah daruriyah, maslahah hajiyah, dan maslahah tahsiniyah. ${ }^{16}$ Aspek hukuman mati dalam hal ini terkategori pada aspek maslahah daruriyah yang secara praksis harus dijaga. Dalam konteks ini terdapat lima elemen yang harus dilestarikan. Pertama, memelihara agama. Kedua, memelihara jiwa. ${ }^{17}$ Ketiga, memelihara akal. Keempat, memelihara keturunan. Kelima, memelihara harta. Oleh karena itu, pidana pembunuhan masuk ke dalam kategori memelihara jiwa.

Sehubungan dengan hukuman yang setimpal (qisas), alQur'an (QS 2:178, 4:92) memperkuat hukum pembunuhan yang telah berjalan di tengah masyarakat Arab pra-Islam. Sudah menjadi kebiasaan di kalangan bangsa Arab di zaman jahiliyah

\footnotetext{
${ }^{15}$ Rasyid, Islam, 186.

${ }^{16}$ Mus\}tafa Sa'id al-Khinn, Aslar al-Ikhtilaf fi al-Qawa'id al-Us\} uliyah fi Ikhtilaf al-Fuqaha' (Beirut: Mu'assasat al-Risalah, 1994), 553.

${ }^{17}$ Memelihara tidak hanya tertuju pada mas\}lah\}ah\} d\}aruriyah, tetapi juga mas\}lah\}ah\} h\}ajiyah, dan mas\}lah\}ah\} tah\}siniyah. Baca Fathurrahman Djamil, Filsafat Hukum Islam Bagian Pertama (Jakarta: Logos Wacana Ilmu, 1997), 129.
}

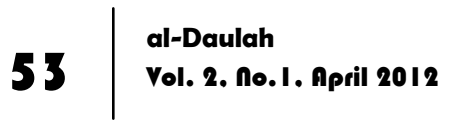


bahwa pembunuhan dibalas dengan pembunuhan, namun tidak jelas aturan pembalasannya. Seringkali pihak keluarga terbunuh menuntut balas lebih banyak atau lebih besar pada pihak keluarga terbunuh. Apabila yang terbunuh seorang anggota keluarga terhormat dari suatu kabilah atau suku, keluarga terbunuh menuntut balas untuk membunuh keluarga si pembunuh dalam jumlah lebih dari satu orang. Apabila pihak keluarga tidak mau menerimanya atau bahkan mengabaikan permintaan keluarga si terbunuh, maka peperangan antara dua keluarga atau kedua suku yang terlibat terjadi, sehingga korban yang jatuh bertambah banyak di kedua belah pihak. ${ }^{18}$

Jika yang dibunuh adalah seorang perempuan dalam satu keluarga, keluarga terbunuh menuntut hukuman balas atas seorang pria dari keluarga si terbunuh yang harus dibunuh, meskipun yang membunuh seorang perempuan adalah perempuan juga. Apabila korbannya seorang budak dari suatu keluarga terbunuh, keluarga pemilik budak biasanya menuntut balas untuk dibunuh adalah anggota keluarga si pembunuh yang orang merdeka. Jika keluarga pembunuh mengabaikan tuntutan pembalasan, biasanya meningkat kepada peperangan antarkeluarga atau antarsuku. Akibatnya, korban yang berjatuhan akan lebih banyak dari kedua belah pihak dan orang yang tidak bersalah akan menjadi korban.

Solusi spesifik al-Qur'an ini memberikan kebebasan kepada keluarga korban untuk memilih antara menuntut balas (qisas) atau meminta sejumlah uang penyelesaian atau ganti rugi (diyah). Di samping itu al-Qur'an juga menambahkan pengampunan atau pemberian maaf dari keluarga korban yang dipandang sebagai kebajikan bernilai tinggi. Solusi al-Qur'an ini memandang pembunuhan sebagai kejahatan terhadap keluarga, sehingga keluarga tersebut bisa menuntut balas atau diyah. Tapi di tempat lain, ketika berbicara tentang pembunuhan yang dilakukan oleh

${ }^{18}$ Abduh Malik, "Kejahatan terhadap Jiwa dalam Perspektif Hukum Pidana Islam," dalam Pidana Islam di Indonesia: Peluang, Prospek, dan Tantangan (Jakarta: Pustaka Firdaus, 200 I), 88. 
Qabil terhadap Habil, al-Qur'an menyatakan bahwa hal itu diibaratkan sebagai pembunuhan secara menyeluruh. Dalam pandangan Rahman, pembunuhan dianggap sebagai kejahatan kemanusiaan, bukan terhadap keluarga korban. Dengan demikian, solusi al-Qur'an dalam QS 2:178 dan 4:92, dimasukkan ke bawah prinsip yang memandang pembunuhan sebagai kejahatan terhadap kemanusiaan. ${ }^{19}$ Menurut penulis, keduanya dapat diterapkan, yaitu pembunuhan dapat dianggap sebagai kejahatan keluarga dan kejahatan kemanusiaan.

Jika qisas hanya dianggap sebagai kejahatan keluarga, hukuman tidak dapat diterapkan jika si korban atau keluarganya memaafkan kesalahan si pelaku, baik ia membayar ganti rugi maupun tidak. Pemberian maaf yang dapat membatalkan hukuman ini, sangat berbahaya bagi masyarakat yang hidup di zaman modern. Dalam hal ini, pihak yang bersalah akan menggunakan segala cara untuk menekan pihak korban untuk memberinya maaf, sehingga ia dapat selamat dari hukuman. Karena mendapat tekanan, si korban dapat mengubah dan memalsukan kesaksian. Dengan demikian, bukti yang ada akan menjadi perdebatan dalam proses persidangan. Jika demikian, sistem tersebut lebih baik disesuaikan dengan kondisi sosial yang aktual dan tidak bertentangan dengan syari'ah. Dalam hal ini, pelaku pembunuhan meskipun mendapatkan pengampunan dari pihak keluarga, dia dapat dikenai sanksi hukuman berupa penjara.

Dalam KUHP, kejahatan terhadap jiwa atau nyawa manusia terbagi atas lima bentuk. Pertama, pembunuhan dengan sengaja. ${ }^{20}$ Kedua, pembunuhan yang direncanakan terlebih dahulu. ${ }^{21}$ Ketiga,

\footnotetext{
${ }^{19}$ Taufik Adnan Amal, Islam dan Tantangan Modernitas: Studi atas Pemikiran Hukum Islam Fazlur Rahman (Bandung: Penerbit Mizan, 1996), 211 -2 12.

${ }^{20}$ Pasal 338 KUHP: "Barangsiapa yang dengan sengaja menghilangkan nyawa orang, karena pembunuhan biasa, dipidana dengan pidana penjara selama-lamanya lima belas tahun.

${ }^{21}$ Pasal I40 KUHP: "Barangsiapa dengan sengaja dan dengan direncanakan lebih dahulu menghilangkan nyawa orang, karena bersalah melakukan pembunuhan berencana, dipidana dengan pidana mati atau penjara seumur hidup atau penjara sementara selama-lamanya dua puluh tahun."
} 
pembunuhan dalam bentuk yang dapat memperberat hukuman. ${ }^{22}$ Keempat, pembunuhan yang dilakukan dengan permintaan sangat dan tegas oleh korban. ${ }^{23}$ Kelima, tindakan seseorang yang dengan sengaja menganjurkan atau membantu atau memberi daya upaya kepada orang lain untuk melakukan bunuh diri. ${ }^{24}$ Selain itu, KUHP juga mengatur tentang kejahatan terhadap seorang anak. Pertama, kejahatan yang ditunjukkan terhadap jiwa seseorang anak yang sedang atau belum lama dilahirkan. ${ }^{25} \mathrm{Kedua}$, Kejahatan yang ditujukan terhadap jiwa seorang anak yang masih dalam kandungan si ibu. ${ }^{26}$

Dalam RUU KUHP, delik pembunuhan biasa dan yang dipikirkan lebih dahulu diatur dalam satu pasal, yaitu "pembunuhan dengan sengaja." Ini sama dengan KUHP negaranegara di Asia yang lain seperti Jepang, Korea, RRC, yang mengenal satu jenis pembunuhan yang disengaja. Begitu pula ketentuan di dalam al-Qur'an, pada surat al-Nisa' ayat 93, yang

22Pasal 339 KUHP: "Pembunuhan biasa dengan diikuti, disertai atau didahului dengan tindak pidana dan yang dilakukan dengan maksud untuk menyediakan atau memudahkan perbuatan itu, atau jika tertangkap tangan untuk melepaskan diri sendiri atau sekutunya daripada pidana, atau supaya barang yang didapatnya dengan melawan hukum tetap ada dalam tangannya, dipidana dengan pidana penjara seumur hidup atau penjara sementara selama-lamanya dua puluh tahun."

${ }^{23}$ Pasal 344 KUHP: "Barangsiapa menghilangkan nyawa orang atau permintaan sungguh-sungguh orang itu sendiri, dipidana dengan pidana penjara selama-lamanya dua belas tahun."

${ }^{24}$ Pasal 345 KUHP: "Barangsiapa dengan sengaja membujuk orang supaya membunuh diri, atau menolongnya dalam perbuatan itu, atau memberi ikhtiar kepadanya untuk itu, dipidana dengan pidana penjara selama-lamanya empat tahun, kalau jadi orangnya membunuh diri."

${ }^{25}$ Pasal 342 KUHP: "Seorang ibu yang untuk menjalankan keputusan yang diambilnya karena takut diketahui orang bahwa ia tidak lama lagi akan melahirkan anak, pada ketika dilahirkan atau tidak lama kemudian daripada itu, dengan sengaja menghilangkan nyawa anaknya itu, karena bersalah melakukan pembunuhan anak berencana, dipidana dengan pidana penjara selama-lamanya sembilan tahun."

${ }^{26}$ Pasal 349 KUHP: "lika seorang dokter, bidan atau juru obat membantu kejahatan tersebut dalam pasal 346, atau bersalah melakukan atau membantu salah satu satu kejahatan diterangkan dalam pasal 347 dan 348, maka pidana yang ditentukan dalam pasal itu dapat diambil sepertiganya dan dapat dicabut haknya melakukan pekerjaannya yang dipergunakan untuk menjalankan kejahatan itu." 
tidak mengenal penbunuhan yang dipikirkan lebih dahulu. ${ }^{27}$ Dengan demikian, semua pembunuhan yang dilakukan dengan tenang adalah pembunuhan dengan dipikir lebih dahulu.

Dalam konteks di atas, menurut penulis, pemberlakuan hukum pidana mati adalah objektif. Secara teoritis hak hidup adalah hak yang paling esensial bagi setiap manusia. Hak ini harus dihormati dan tidak boleh dirampasnya. Di dalam hak hidup itu terkandung kewajiban, yakni menghormati dan menjaga hidup. Oleh karena itu, syari'ah melarang dan tidak membenarkan menghilangkan nyawa seseorang, bahkan terhadap dirinya sendiri. Dalam kondisi demikian, yang menjadi persoalan adalah penerapan hukuman mati bagi pelaku tindak pidana pembunuhan.

Berdasarkan al-Qur'an, perbuatan pidana yang dilakukan orang yang bertanggung jawab diberi hukuman tertentu dengan keadilan menurut petunjuk Allah. ${ }^{28}$ Untuk itu, hukuman pidana didasarkan kepada wahyu dan akal sehat manusia dengan setting demi kemaslahatan manusia, di dunia maupun di akhirat. Dengan demikian, penerapan hukuman mati justru untuk melestarikan hak hidup dan nilai-nilai kemanusiaan. Jika dibiarkan tanpa sanksi yang seimbang bagi pelaku pembunuhan, manusia semakin menginjak hak hidup orang lain dan menegasikan nilai-nilai kemanusiaan yang bersifat universal. Minimal, penerapan hukuman itu menjadi pelajaran bagi orang lain dan sebagai langkah strategi preventif terhadap munculnya berbagai macam pembunuhan.

\footnotetext{
${ }^{27}$ Andi Hamzah, "Kejahatan terhadap Nyawa dan Harta: Perspektif Hukum Pidana Islam dan Barat," dalam Pidana Islam di Indonesia: Peluang, Prospek, dan Tantangan (Jakarta: Pustaka Firdaus, 200 I), 169.

${ }^{28}$ Rachmat Djatnika, "Filsafat Hukum Islam dalam Berbagai Bidang," dalam Filsafat Hukum Islam (Jakarta: Proyek Pembinaan Prsarana dan Sarana Perguruan Tinggi Agama/IAIN di Jakarta Direktorat Jenderal Pembinaan Kelembagaan Agama Islam Departemen Agama, 1987), 183.
} 
Konkretnya, membunuh yang dilarang adalah perbuatan yang bernilai jelek..$^{29}$ Membunuh yang berdasarkan hukum untuk melindungi kemaslahatan jiwa seluruh masyarakat, yakni untuk melestarikan hak hidup orang lain dan nilai-nilai kemanusiaan, menurut hemat penulis justru adalah sikap konsisten dan bertanggung jawab. Hukuman mati yang dijatuhkan berdasarkan hukum atau undang-undang, nilainya tidak sama dengan membunuh yang tidak berdasarkan hukum atau melawan hukum.

Syari'ah memandang, perbuatan melanggar hukum tidak dalam satu derajat yang sama. Setiap derajat diancam dengan hukuman sesuai dengan berat dan ringannya kejahatan dalam pandangan Tuhan, bukan dalam pandangan manusia. ${ }^{30}$ Oleh karena itu, hukuman atas suatu perbuatan harus setimpal dengan kejahatan yang dilakukan. Membunuh, hukuman yang setimpal adalah perbuatan yang serupa. Jika orang yang membunuh dijatuhi hukuman penjara tiga tahun, misalnya, secara jurudis hukuman itu tidak setimpal dan secara psikologis pihak keluarga terbunuh merasa tidak puas.

Aspek ketidakpuasan dari pihak keluarga terbunuh di atas, secara filosofis, menjadi perhatian syari'ah. Rasa dendam perlu diantisipasi agar tidak terjadi pembunuhan berangkai. Untuk itu, syari'ah lebih mementingkan kemaslahatan umum daripada kemaslahatan pribadi. Jika kemaslahatan pembunuh lebih dikedepankan, sangat besar kemungkinannya, kemaslahatan umum tidak tercapai. Dalam hal ini, dendam pembunuhan mendapat jalan. Konsekuensinya, pembunuhan kedua kali dapat terjadi, demikian seterusnya.

Terkait dengan hak hidup bagi pelaku pembunuhan, syari'ah sangat menghargai. Hanya saja, syari'ah tidak memperkenankan membunuh orang lain tanpa alasan. Jika hakim menghukum

\footnotetext{
${ }^{29}$ Sudjari Dahlan, Masalah Hukuman Mati dan Relevansinya dengan Kemanusiaan (Surabaya: Biro Penerbitan dan Pengembangan Perpustakaan Fakultas Syariah Surabaya IAIN Sunan Ampel, 1990), 69.

${ }^{30}$ Rasyid, Islam, 187.
} 
pelaku tindak pidana dengan hukuman mati, kapasitasnya dia sebagai pelaksana perintah Tuhan yang berkuasa penuh pada manusia. Hakim pada dasarnya tidak membunuh pelaku tindak pidana, tetapi dia sebagai pelaksana peraturan Tuhan yang diakui kebenarannya.

Untuk itu, manusiawi dan tidaknya hukum Tuhan tidak dilihat dari satu aspek dengan memperhatikan kepentingan personal, tetapi ditekankan pada aspek lain yang lebih besar, yaitu menjaga ketenteraman dan ketertiban masyarakat secara totalitas. Hukuman qisas yang diundangkan Allah menjamin perlindungan terhadap hak asasi manusia. Pemberlakukan hukuman qisas mengaksentuasikan agar tidak terjadi pertumpahan darah. Syari'ah sangat menghargai nilai setetes darah. Jika orang yang mengalirkan darah tidak divonis dengan hukuman yang setimpal, maka darah manusia sudah tidak bernilai.

Dengan memperhatikan kepentingan yang lebih besar, hukuman mati mempunyai pengertian mempertahankan hak hidup manusia. Dalam hal ini hak manusia mencakup dua kewajiban. Pertama, kewajiban bagi yang berhak menjaga hidupnya dan mempergunakan sebaik-baiknya untuk kepentingan diri sendiri dan masyarakat. Kedua, kewajiban bagi orang lain agar menghormati hak dan tidak menggaggunya. Jika hak hidup diganggu dengan dibunuh, sewajarnya pelaku diberi hukuman yang keras, yakni hukuman yang setimpal supaya pembunuhan yang lebih luas dapat dieliminir.

Di samping itu, diyah sebagai pengganti qisas juga merupakan jalan keluar bagi pembunuh jika pihak keluarga korban mengampuni. Dalam hal ini faktor pihak keluarga merupakan keringanan dari Allah, baik kepada manusia secara umum maupun kepada manusia secara individual. Dengan demikian, kepentingan pihak yang terkait dan kepentingan pihak masyarakat dipertimbangkan dengan benar dan bijaksana.

Karena masalah di atas terkait dengan pihak keluarga, hakim sebelum memutuskan perkara wajib menanyakan kehendak 
keluarga, apakah mereka dengan ikhlas memaafkan terdakwa atau tidak. Bila keluarga dengan ikhlas memaafkan terdakwa, maka kewajiban hakim selanjutnya adalah memutuskan. ${ }^{31}$ Artinya, ia menetapkan kelayakan jumlah denda yang harus dibayarkan kepada pihak keluarga korban dengan mempertimbangkan asas keadilan.

\section{Penerapan Hukum Pidana Mati menurut Syari'ah dalam} Konteks Indonesia

Eksistensi lembaga hukuman mati dalam syari'ah yang berupa sanksi telah dinyatakan dengan tegas di dalam al-Qur'an. Hal ini tidak dapat diingkari oleh umat Islam. Hanya saja dalam penerapan proses penetapan, hakim harus bertindak hati-hati dan selektif.

Pada saat proses pemeriksaan dan pemutusan perkara yang berlaku di persidangan peradilan umum, hakim mengenal dua tahapan kerja sebelum sampai pada putusan yang harus dijatuhkan. Tahap pertama, hakim akan melakukan pembuktian terhadap seluruh perbuatan yang didakwakan pada terdakwa. Apabila secara objektif ternyata seluruh perbuatan terdakwa memenuhi segenap unsur yang termuat dalam pasal-pasal yang didakwakan, maka hakim akan memproses lebih lanjut. Tahap kedua, hakim menilai dengan yakin bahwa perbuatan terdakwa benar-benar terjadi. ${ }^{32}$

Jika pada tahap kerja pertama, hakim berdakwa secara objektif berdasarkan adanya beberapa faktor yang menjadi pertimbangan, maka tahap kedua hakim harus bersikap subjektif. Artinya, dia harus berdialog dengan hati nuraninya untuk sampai pada keyakinan dalam menetapkan hukum. Konsepsi ini tertuang dalam pasal 6 ayat (2) UU No. 14 Tahun 1970 tentang Ketentuanketenuan Pokok Kekuasaan Kehakiman yang berbunyi:

31 Mardjono, Menegakkan, 126.

${ }^{32}$ lbid., 124. 
Tiada seorang juapun dapat dijatuhi pidana, kecuali apabila Pengadilan, karena alat pembuktian yang sah menurut undangundang, mendapat keyakinan bahwa seseorang yang dianggap dapat bertanggung jawab telah bersalah atas perbuatan yang dituduhkan atas dirinya.

Pasal tersebut kemudian dipertegas oleh pasal 183 UU No. 8 Tahun 1981 tentang Kitab Undang-undang Hukum Acara Pidana yang berbunyi:

Hakim tidak boleh menjatuhkan pidana kepada seseorang kecuali dengan sekurang-kurangnya dua alat bukti yang sah di mana ia memperoleh keyakinan bahwa suatu tindak pidana benarbenar terjadi dan bahwa terdakwalah yang bersalah melakukannya.

Dari ketentuan itu, proses penjatuhan putusan di lingkungan Pradilan Umum hanya mengenal dua tahap kerja hakim. Penerapan ini berbeda dengan ketentuan yang berlaku di lingkungan peradilan yang berdasarkan syari'ah. Hal ini tertuang dalam firman Allah:

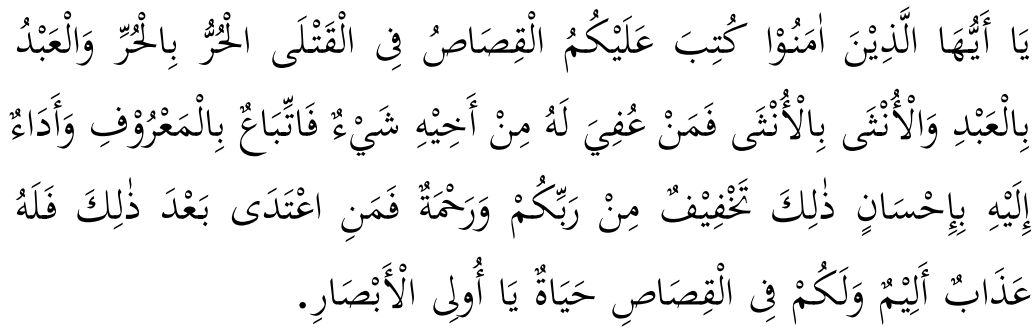

Wahai orang-orang yang beriman, diwajibkan atas kalian qisas berkenaan dengan orang-orang yang dibunuh; orang merdeka dengan orang merdeka, hamba dengan hamba, dan wanita dengan wanita. Oleh karena itu, barangsiapa mendapat pemaafan dari saudaranya, hendaklah yang memaafkan mengikuti dengan cara yang baik dan hendaklah (yang diberi maaf) membayar diyah kepada yang memberi maaf dengan cara yang baik pula. Yang demikian itu adalah suatu keringanan dari Tuhan kalian dan suatu rahmat. Barangsiapa melampaui batas sesudah itu, 
maka baginya siksa yang pedih. Di dalam qisas itu ada (jaminan kelangsungan) hidup bagi kalian wahai orang-orang yang berakal supaya kalian bertakwa. ${ }^{33}$

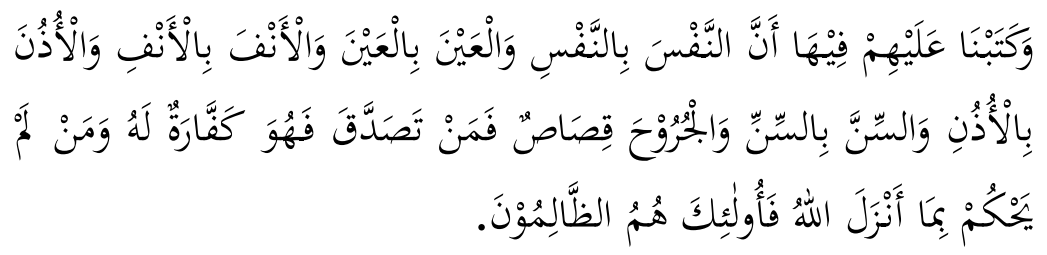

Dan telah Kami tetapkan terhadap mereka di dalamnya (Taurat) bahwa jiwa (dibalas) dengan jiwa, mata dengan mata, hidung dengan hidung, telinga dengan telinga, gigi dengan gigi, dan lukapun ada balasannya. Barangsiapa yang melepaskan hak qisasnya, maka melepaskan hak itu menjadi penebus dosa baginya. Barangsiapa tidak menentukan perkara menurut apa yang dirurunkan Allah, maka orang itu adalah orang yang aniaya. ${ }^{34}$

Jika dikaji secara akurat, sebenarnya firman Allah di atas merupakan jalan keluar yang sangat baik untuk memecahkan masalah yang pro dan kontra dan merupakan solusi metodologis dan praksis terhadap eksistensi lembaga hukuman mati. Dalam konsep ini, eksistensi hukuman mati telah diakui dengan tegas. Hanya saja dalam penerapan kasus-perkasus, faktor kehendak keluarga korban harus diperhatikan yang merupakan keringanan dari Allah, baik kepada manusia secara totalitas maupun secara individual. Dengan demikian, kepentingan pihak yang terkait dan kepentingan umum masyarakat harus dipertimbangkan dengan benar dan bijaksana.

Tahap kerja semacam itu dilakukan hakim sebelum memutus perkara. Ia wajib menanyakan kehendak keluarga, apakah mereka dengan ikhlas akan memberi maaf kepada terdakwa atau tidak. Bila keluarga korban dengan ikhlas memaafkan terdakwa, maka

\footnotetext{
2'al-Qur'an, 2: 178- 179.

${ }^{34}$ Ibid., 5:45.
} 
kewajiban hakim selanjutnya adalah memutuskan. ${ }^{35}$ Artinya, ia menetapkan kelayakan jumlah denda yang harus dibayarkan kepada pihak keluarga korban dengan mempertimbangkan asas keadilan.

Formulasi di atas mendeskripsikan bahwa syari'ah mengajarkan tahapan kerja secara objektif. Hakim tidak saja dituntut cermat dan objektif dalam membuktikan, tetapi ia dituntut memperhatikan kehendak ikhlas pihak keluarga korban. Kedua pilar ini menjadi sandaran bagi hakim untuk menetapkan hukum. Dengan demikian, penerapan hukum Islam sangat kontekstual jika ditransformasikan dalam sistem peradilan di Indonesia. Nilai fleksibelitas, transparan, dan kompromististis sangat tampak.

Jika dikaji lebih jauh, al-Qur'an dan al-Sunnah mengakui dan membenarkan kontrol individu seseorang melalui inisiasi pidana (pembunuhan). Al-Qur'an dan al-Sunnah juga memberi pilihan antara qisas dan membayar diyah, tanpa meniadakan kepentingan publik. Dalam hal ini-suatu contoh-kebijaksanaan tidak menuntut dan memilih cara hukuman bagi korban atau sanak familinya dapat digunakan melalui berbagai mekanisme yang tepat. Pemberlakuan sistem semacam ini masih tetap berpijak kepada kontrol publik yang diakui. ${ }^{36}$

Selain dari keterangan di atas, ada beberapa hal urgen yang perlu ditelaah, yakni prinsi-prinsip umum tangung jawab pidana (criminal respensiblity) yang secara umum masyarakat telah menerima sebagai kebutuhan untuk menentukan elemen mental dan fisik yang bisa dimasukkan sebagai kejahatan. Oleh karena itu, kompleksitas tindak pidana memerlukan pertimbangan umum tentang berbagai hal, misalnya tentang perencanaan kejahatan, persekongkolan dengan orang lain untuk melakukan pelanggaran

\footnotetext{
${ }^{35}$ Mardjono, Menegakkan, 126.

${ }^{36}$ Lihat Abdullahi Ahmed An-Na'im, Dekonstruksi Syari'ah, ter. Ahmad Suaedy dan Amiruddin Arrani (Yogyakarta: LKIS Bekerjasama dengan Pustaka Pelajar, 1994), 222.
}

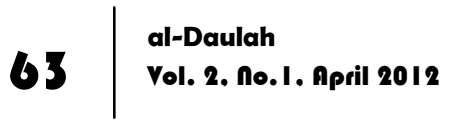


pidana, dan tanggung jawab bersama bagi beberapa orang yang terlibat dalam satu pelanggaran pidana. ${ }^{37}$

Sebagai contoh, legislasi harus menentukan apa dan bagaimana tanggung jawab hukumnya jika terdapat fakta bahwa seorang anggota persekongkolan adalah anak kecil atau cacat fisik. Hakim tidak boleh memutuskan hal itu hanya dengan persetujuan pihak keluarga korban apakah dengan qisas atau dengan diyah secara kompromistis, tetapi ia harus menunjukkan berbagai persoalan ke berbagai aspek. Dengan demikian, pelaksanaan hukum qisas akan berjalan secara utuh dan terarah.

Berbagai paparan di atas memperlihatkan bahwa hukum pidana mati dalam syari'ah secara konsepsional dan praktikal telah terelaborasi sercara konkret. Hanya saja, kebanyakan ahli hukum kurang memahami secara utuh dan tuntas aspek falsafinya, sehingga mereka seringkali memandang bahwa hukum Islam adalah kejam dan mengenaskan. Bahkan mereka berasumsi, hukum Islam tidak elastis dan tidak manusiawi. Untuk itu-agar tidak salah persepsi-hukum Islam harus dipandang dari aspek kondisional dan universal. Di dalam hukum Islam, kedua aspek itu sangat berangkai

\section{Penutup}

Dari berbagai formulasi di atas dapat diambil dua kesimpulan sebagai berikut:

1. Menurut syari'ah, hukum pidana Islam adalah hukum yang setimpal; orang yang membunuh, dia harus dibunuh kecuali jika pihak keluarga terbunuh memberikan pengampunan atau meminta ganti rugi. Dalam hal ini, hukum pidana mati tidak hanya dilihat dari segi vonis. Lebih dari itu, hukuman itu harus dilihat dari segi kemaslahatan secara totalitas, bukan kemaslahatan secara parsial. Dengan demikian, hukum pidana

${ }^{37}$ Ibid., 229-230. 
mati pada hakikatnya untuk menjaga hak hidup orang lain demi keadilan dan melesatrikan nilai-nilai kemanusiaan.

2. Dalam pemeriksaan dan pemutusan perkara yang berlaku di persidangan Peradilan Umum, hakim menerapkan dua tahapan kerja. Pertama, hakim menyeleksi adanya pembuktian seluruh perbuatan yang didakwakan pada terdakwa. Kedua, hakim menilai dengan keyakinan bahwa perbuatan terdakwa benarbenar terjadi. Sedang menurut hukum pidana Islam, selain dari proses pemeriksaan dan pemutusan perkara yang terdapat di persidangan Peradilan Umum, hakim masih melibatkan pihak keluarga korban. Artinya, hakim masih menanyakan pada pihak keluarga korban tentang kerelaannya untuk memberikan maaf kepada terdakwa. Dengan demikian, penerapan hukum pidana mati menurut syari'ah dalam konteks Indonesia sangat fleksibel, transparan, dan manusiawi.

\section{Daftar Pustaka}

Ali, Atabik dan Muhdlor, Ahmad Zuhdi. Kamus Kontemporer ArabIndonesia. Yogyakarta: Yayasan Ali Maksum Pondok Pesantren Krapyak Yogyakarta, 1997.

Amal, Taufik Adnan. Islam dan Tantangan Modernitas: Studi atas Pemikiran Hukum Islam Fazlur Rahman. Bandung: Penerbit Mizan, 1996.

Dahlan, Sudjari. Masalah Hukuman Mati dan Relevansinya dengan Kemanusiaan. Surabaya: Biro Penerbitan dan Pengembangan Perpustakaan Fakultas Syariah Surabaya IAIN Sunan Ampel, 1990.

Djamil, Fathurrahman. Filsafat Hukum Islam Bagian Pertama. Jakarta: Logos Wacana Ilmu, 1997.

Djatnika, Rachmat. "Filsafat Hukum Islam dalam Berbagai Bidang," dalam Filsafat Hukum Islam. Jakarta: Proyek Pembinaan Prsarana dan Sarana Perguruan Tinggi

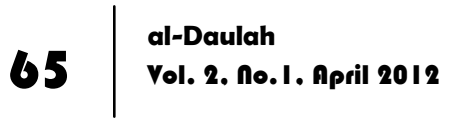


Agama/IAIN di Jakarta Direktorat Jenderal Pembinaan Kelembagaan Agama Islam Departemen Agama, 1987.

Doi, 'Abbdur Rahman I. Shari'ah: The Islamic Law. Malaysia: A.S. Noorden Kuala Lumpur, 1996.

Glasse, Cyril. Ensiklopedi Islam. ter. Ghufron A. Mas'adi. Jakarta: PT Raja Grafindo Persada, 1996.

Hamzah, Andi. "Kejahatan terhadap Nyawa dan Harta: Perspektif Hukum Pidana Islam dan Barat," dalam Pidana Islam di Indonesia: Peluang, Prospek, dan Tantangan. Jakarta: Pustaka Firdaus, 2001.

al-Khinn, Mustafa Sa'id. Asar al-Ikhtilaf fi al-Qawa'id al-Usuliyah fi Ikhtilaf al-Fuqaha'. Beirut: Mu'assasat al-Risalah, 1994.

Malik, Abduh. "Kejahatan terhadap Jiwa dalam Perspektif Hukum Pidana Islam," dalam Pidana Islam di Indonesia: Peluang, Prospek, dan Tantangan. Jakarta: Pustaka Firdaus, 2001.

Mardjono, Hartono. Menagakkan Syariat Islam dalam Konteks Keindonesiaan: Proses Penerapan Nilai-nilai Islam dalam Aspek Hukum, Politik, dan Lembaga Negara. Bandung: Penerbit Mizan, 1997.

Mu'allim, Amir dan Yusdani. Ijtihad: Suatu Kontroversi antara Teori dan Fungsi. Yogyakarta: Penerbit Titian Ilahi Press, 1997.

Musa, Kamil. al-Madkhal ila al-Tasyri' al-Islami. Beirut:Mu'assasat al-Risalah, t.t.

Muslehuddin, Muhammad. Filsafat Hukum Islam dan Pemikiran Orientalis: Studi Perbandingan Sistem Hukum Islam. ter. Yudian Wahyudi Asmin. Yogyakarta: Penerbit PT Tiara Wacana Yogya, 1991.

An-Na'im, Abdullahi Ahmed. Dekonstruksi Syari'ah. ter. Ahmad Suaedy dan Amiruddin Arrani. Yogyakarta: LKIS Bekerjasama dengan Pustaka Pelajar, 1994.

Qutb, Sayyid. Haza al-Din (The Religion of Islam). USA: IIFSO Publication Undated, t.t.

Rasyid, Daud. Islam dalam Berbagai Dimensinya. Jakarta: Gema Insani Press, 1998. 
Schacht, Joseph. An Introduction to Islamic Law. London: Oxford at the Clrarendon Press, 1971.

-------. “Problem of Modern Islamic Legislation," dalam Studia Islamica. vol. 12. t.t.p.: t.p., 1960. 